\title{
SUPERENDIVIDAMENTO DO CONSUMIDOR: PREVENÇÃO E TRATAMENTO SOB O PRISMA DA DIGNIDADE DA PESSOA HUMANA
}

Andressa Pereira"

Margareth Vetis Zaganelli**

SUMÁRIO: Introdução; 2 Conceito da expressão; 2.1 Superendividamento ativo e passivo, consciente e inconsciente; 3 Possiveis causas do superendividamento do consumidor; 3.1 Motivação econômica; 3.2 Motivação psicológica; 3.3 Motivação social; 4 Uma breve visão geral do tratamento da questão nas legislações dos países estrangeiros; 4.10 sistema francês; 4.20 sistema norte-americano; 4.3 Os casos de Itália e Colômbia; 50 tratamento dado ao superendividamento do consumidor no Brasil; 5.1 o projeto-piloto "Tratamento das situações de superendividamento do consumidor"; 5 O projeto de lei do Senado Federal no 283/2012; 6 Conclusão; Referências.

RESUMO: $O$ presente trabalho tem por intento abordar a temática do superendividamento do consumidor, um fenômeno que se apresenta de forma globalizada e que coloca em risco a dignidade da pessoa humana; nesse caso, o consumidor. Preliminarmente, utilizando metodologia descritiva, pesquisa bibliográfica e documental, à luz do direito comparado, analisa-se o conceito de tal fenômeno, as possíveis causas para a sua manifestação e as suas implicações sociais e jurídicas. A seguir, descreve-se como tal problema vem sendo solucionado em outros ordenamentos jurídicos e como o direito brasileiro tem procurado tratar esse problema. O estudo tem por fito ressaltar que o superendividamento do consumidor é uma dificuldade que, não somente necessita de instrumentos legais para o seu enfrentamento, dentre outros no sentido de assegurar o respeito à dignidade da pessoa humana, mas também de elementos provenientes de outras ciências, com a apresentação de métodos que auxiliem na solução para o problema discutido.

PALAVRAS-CHAVE: Superendividamento do consumidor; Crédito; Débito; Dignidade da pessoa humana; Ato legislativo.

\footnotetext{
"Bacharel em Direito pela Universidade Federal do Espírito Santo (UFES). Advogada. Brasil.

* Doutora em Direito pela Universidade Federal de Minas Gerais (UFMG). Docente Titular de Direito Penal e Processual Penal e de Teoria do Direito da Universidade Federal do Espírito Santo (UFES). Docente Permanente do Programa de Pós-Graduação em Gestão Pública da Universidade Federal do Espírito Santo (UFES). Coordenadora do Grupo de Estudos e Pesquisas Direito \& Ficção. Brasil. E-mail: mvetis@terra.com.br
} 


\title{
HIGHLY INDEBTED CONSUMER: PREVENTION AND TREATMENT FROM THE POINT OF VIEW OF THE DIGNITY OF THE HUMAN PERSON
}

\begin{abstract}
Current analysis investigates the theme of the highly indebted consumer, a worldwide phenomenon that endangers the dignity of the human person, or rather, the consumer. The descriptive, bibliographical and documentary analysis deals with the phenomenon and its possible causes, coupled to social and juridical implications. It also describes how the issue is being solved within juridical stances and the manner Brazilian law is treating the issue. Current analysis underscores that consumers' high debts is such a big issue that it requires legal tools to face it to warrant the dignity of the human person and instruments from other sciences which bring forth methods that would solve the issue.
\end{abstract}

KEY WORDS: Highly indebted consumer; Credit; Debit; Dignity of the human person; Rule of parliamentt.

\section{SÚPER ENDEUDAMIENTO DEL CONSUMIDOR: PREVENCIÓN Y TRATAMIENTO BAJO EL PRISMA DE LA DIGNIDAD DE LA PERSONA HUMANA}

RESUMEN: En el presente estudio se tiene por intento abordar la temática del súper endeudamiento del consumidor, un fenómeno que se presenta de forma globalizada y que pone en riesgo la dignidad de la persona humana; en ese caso, el consumidor. Preliminarmente, utilizando metodología descriptiva, investigación bibliográfica y documental, a la luz del derecho comparado, se analiza el concepto de tal fenómeno, las posibles causas a su manifestación y sus implicaciones sociales y jurídicas. A seguir, se describe cómo tal problema viene siendo solucionado en otros ordenamientos jurídicos y cómo el derecho brasileño ha procurado tratar ese problema. El estudio tiene por objetivo poner de relieve que el súper endeudamiento del consumidor es una dificultad que, no solo necesita de instrumentos legales para su enfrentamiento, entre otros en el sentido de asegurar el respeto a la dignidad de la persona humana, sino también de elementos provenientes de otras ciencias, con la presentación de métodos que ayuden en la solución para el problema discutido.

PALABRAS CLAVE: Súper endeudamiento del consumidor; Crédito; Débito; Dignidad de la persona humana; Acto legislativo. 


\section{INTRODUÇÃO}

Desde a Antiguidade o ser humano preocupa-se em tratar dos casos nos quais os indivíduos se mostram incapazes de honrar com as obrigações que contratou. $\mathrm{Na}$ Roma Antiga o credor poderia escolher, em um sistema que favorecia a vingança pessoal, a forma de compensar o inadimplemento do devedor, tendo permissão das normas legais para afligir o corpo do detentor da dívida, caso assim escolhesse. ${ }^{03}$

Com o passar dos anos houve mudança no foco de compreensão do sistema legal de cobrança de débitos - mudou-se o eixo do pagamento centralizado na própria pessoa do devedor, para o seu patrimônio. ${ }^{04}$ Percebe-se assim, da Carta Magna inglesa, em 1215, até a Constituição Americana de Direitos de 1787, uma mudança de abordagem, agora patrimonial, para o tema do endividamento. ${ }^{05}$

No Brasil, uma pesquisa elaborada pela Confederação Nacional do Comércio de Bens, Serviços e Turismo (CNC), com aproximadamente 18 mil consumidores, concluiu que, no mês de abril de 2018, 60,2\% das famílias brasileiras são endividadas, sendo que, entre a porcentagem apresentada, 10,3\% dessas famílias não conseguirão, de forma alguma, adimplir seus débitos ${ }^{06}$. Em nível global pode ser citado o levantamento realizado pela Comissão Europeia, em 2010, que concluiu que $4.6 \%$ das famílias europeias tinham débitos que comprometiam a totalidade de sua renda. ${ }^{07}$

O presente trabalho tem como foco a busca pela compreensão de um conceito contemporâneo que trata justamente dos casos de endividamento excessivo por parte das pessoas naturais, o superendividamento do consumidor, bem como, ao final, a apresentação de possíveis soluções para tal problema. Incialmente, o foco será o da busca pelo entendimento do conceito em si, e das nuances que o integram e constroem.

Sequencialmente, serão trabalhadas as possíveis causas do fenômeno do superendividamento do consumidor, em diferentes perspectivas, buscando análises

\footnotetext{
${ }^{03}$ ROJAS VERTIZ, Rosa, Is There Consumer Bankruptcy in Latin America? The Cases of Colombia, Brazil and Peru, 2017. Disponivel em https://ssrn.com/abstract=2996808. p. 3

${ }^{04}$ ROJAS VERTIZ, Rosa. Op. Cit. p. 3

${ }^{05}$ ROJAS VERTIZ, Rosa. Op. Cit. p. 3

06 CONFEDERAÇÃO NACIONAL DO COMÉRCIO DE BENS, SERVIÇOS E TURISMO. Pesquisa Nacional de Endividamento e Inadimplência do Consumidor, 2018. Disponível em: http://cnc.org.br/central-doconhecimento/pesquisas/economia/pesquisa-de-endividamento-e-inadimplencia-do-consumidor-3. p. 1.

${ }^{07}$ COMISSÃO EUROPEIA. Over-indebtedness - New evidence from the EU-SILC special module. Research note 4/2010, Social Situation Observatory - Living Conditions and Income Distribution 2010. Disponível em: ec.europa.eu/social/BlobServlet?docId=6708\&langId=en. p. 32 .
} 
econômicas, psicológicas e sociais do tema em abordagem, para compreensão da sua formação mosaica e diversa, assim, complexa.

Em seguida, será feita uma abordagem do tratamento dado ao tema por alguns países que possuem mecanismos judiciais e administrativos para tentativa de mitigação dos casos de superendividamento do consumidor que já se encontram consolidados e também mecanismos que buscam prevenir a criação de novos casos de débitos exacerbados pelas pessoas naturais.

Na sequência serão analisadas as medidas legais e administrativas que vem sendo tomadas pelo Brasil na tentativa de solucionar o problema do endividamento excessivo dos consumidores, em que será apresentado o projeto de lei no 3515/2015 em tramitação na Câmara dos Deputados que busca trazer uma regulação a fim de evitar o superendividamento do consumidor.

Por fim, será apresentada uma conclusão com a apresentação das medidas que parecem, após a análise de todos os fatores apresentados, as melhores para ajudar a solucionar o superendividamento do consumidor no caso brasileiro, tendo esse artigo a pretensão de servir como um ponto de estudo e auxílio na compreensão e na busca de soluções para o problema apresentado.

\section{CONCEITO DA EXPRESSÃO}

A definição de superendividamento do consumidor é variável e depende do contexto sociocultural em que é produzida. Mesmo dentro de um único país é possível encontrar definições diferentes para a expressão a depender da abordagem de estudo do autor que a constrói.

Para alguns autores, o superendividamento do consumidor se resume à situação quando o devedor se vê impossibilitado economicamente de cumprir com suas obrigações e sanar seus débitos. ${ }^{08}$

Outra definição apresentada, essa pela doutrina italiana, é de que ocorre o superendividamento do consumidor quando o devedor se encontra, de forma permanente, impossibilitado de pagar todas as suas dívidas, ou ainda, quando se

\footnotetext{
${ }^{08}$ ANDRADE, Fabio Siebeneichler, ROSA, Taís Hemann da. Notas Sobre a Tutela do Consumidor Superendividado no Brasil: um novo caso de proteção da pessoa contra si mesmo (atualidades e perspectivas). Revista Arquivo Jurídico - Revista Jurídica Eletrônica da UFPI, v. 2, 2015. p. 6
} 
exista um perigo real de que o devedor não possa adimplir seus débitos vincendos. ${ }^{09}$

$\mathrm{Na}$ legislação desse país, define-se o superendividamento como uma situação de desequilíbrio persistente entre as obrigações assumidas e os ativos que podem ser prontamente liquidados para saldá-las, o que determina a dificuldade significativa em cumprir as obrigações de uma pessoa, ou a incapacidade definitiva de adimpli-las regularmente. ${ }^{10}$

Há quem defina o superendividamento também como a situação na qual o consumidor não consegue saldar as obrigações, de cunho financeiro, contraídas sem que coloque em risco a sua própria subsistência. ${ }^{11}$

$\mathrm{Na}$ doutrina brasileira, destaca-se a definição trazida por Cláudia Lima Marques ao definir o tema. Para a mencionada autora, o fenômeno caracteriza-se por ser a impossibilidade de um devedor, na condição de pessoa física, quando ocupando a posição de consumidor leigo na relação de consumo, pague as dívidas que contraiu, tanto as do tempo presente quanto às por vencer, quando as tenha contratado de boa-fé. ${ }^{12}$

Voltando-se para as definições apresentadas, percebe-se que o ponto comum e de convergência entre elas é o de que quando superendividado, o consumidor encontra-se impossibilitado de adimplir as obrigações que contraiu.

Uma abordagem que resume tal ideia é a que se faz presente na definição trazida por Maria Manuela Leitão Marques, que define como a impossibilidade do consumidor de boa-fé cumprir com suas dívidas vencidas e a vencer. ${ }^{13}$

Desse modo, pode-se definir o superendividamento como a condição na qual o consumidor, pessoa física, encontra-se numa posição em que contraiu débitos superiores a sua capacidade de adimplemento, não podendo assim honrar com os pagamentos contemporâneos em que é devedor, como também comprometendo os pagamentos futuros referentes às obrigações diferidas que contraiu.

$\overline{09}$ BERTUZZI, Martina. Il sovraindebitamento del consumatore. Università Degli Studi di Roma "Roma Tre". Quinto premio OCI per laureati con tesi sulle discipline concorsuali della crisi d'impresa, 2016. p. 7.

${ }^{10}$ CONDINO, Olivia. Il sovraindebitamento del consumatore. Il Diritto degli Affari, E-Book n. 4, Milano. pag. 8.

${ }^{11}$ QUEIROZ, Sheyla Cristina Ferreira dos Santos. Superendividamento do Consumidor: os contratos de crédito pessoal por idosos e a responsabilidade penal do fornecedor. Dissertação (Mestrado em Ciências Jurídicas) Universidade Federal da Paraíba, João Pessoa, 2016. p. 78

12 PRUX, Oscar Ivan. Os 25 anos do Código de Proteção e Defesa do Consumidor, sua história e as novas perspectivas para o século XXI. Revista de Direito do Consumidor, v. 104, Revista dos Tribunais, 2016., p. 22, Apud LIMA, Clarissa Costa de. O tratamento do superendividamento e o direito de recomeçar dos consumidores, São Paulo: Ed. RT, 2014. p. 9

13 SCHMIDT NETO, André Perin. Superendividamento do consumidor: conceito, pressupostos e classificação. Revista de Direito do Consumidor, v. 71, 2009., pag. 4, apud MARQUES, Maria Manuel Leitão; FRADE, Catarina; NEVES, Vitór; LOBO, Flora; PINTO, Paula; CRUZ, Cristina. O endividamento dos consumidores. Coimbra: Almedina, 2000, p. 235. 


\subsection{SUPERENDIVIDAMENTO PASSIVO E ATIVO, CONSCIENTE E INCONSCIENTE}

O superendividamento pode ser dividido, para melhor compreensão do tema, em categorias de classificação. Relacionado ao aspecto da causa do fenômeno tem-se o denominado superendividamento passivo e o ativo.

Esse segundo pode sofrer ainda uma nova forma de classificação, ligado ao caráter subjetivo da análise, ou seja, ligado à pessoa do consumidor, em que se tem o denominado superendividamento ativo consciente e o inconsciente.

O superendividamento passivo do consumidor pode ser entendido como aquele no qual a pessoa se vê endividada por um motivo exterior a si, ao qual não deu causa. Observado por esse viés, pode-se dizer que a causa do endividamento excessivo não foi um mau gerenciamento por parte do consumidor dos débitos que contratou. ${ }^{14}$

Observa-se, na verdade, que o fator gerador do endividamento foi um evento alheio a ele, sobre o qual não poderia ter controle, e que acaba por causar um desequilíbrio financeiro capaz de ferir a capacidade que ele antes tinha de honrar com suas obrigações. ${ }^{15}$

Quando se faz menção, por sua vez, ao superendividamento ativo, está se falando daquele endividamento exacerbado causado por ações praticadas pelo próprio consumidor. Nesse quadro, o consumidor contrai, voluntariamente, débitos superiores ao que tem condição de adimplir. ${ }^{16}$

Dessa maneira, no plano ativo, a causa do fenômeno é interna, sendo o próprio indivíduo o responsável por praticar as ações que o originam. É a partir desse ponto que se parte para que seja feita a distinção entre superendividamento ativo consciente e inconsciente, na qual é feita uma análise da boa-fé do consumidor na contratação desses débitos.

A busca pela compreensão da presença da boa-fé mostra-se importante no aspecto que muitas das medidas existentes para tutela do consumidor

\footnotetext{
${ }^{14}$ PALHARES, Cinara. A tutela do consumidor excessivamente endividado como forma de preservação dos direitos fundamentais da pessoa humana. Dissertação (Mestrado em Direito Civil) - Faculdade de Direito, Universidade de São Paulo, São Paulo, 2010. p 50

${ }^{15}$ LIMA, Bruna Giacomini; FERREIRA, Vitor Hugo do Amaral. Da Ruína à Reconstrução do Homo Economicus: Os (Des) Encontros da Sociedade de Consumo na Interface do Direito, Cidadania e Políticas Públicas. Seminário Internacional de Demandas Sociais e Políticas Públicas na Sociedade Contemporânea, 2015. p. 6

16 CARVALHO, Diógenes Faria de ; FERREIRA, Vitor Hugo do Amaral. Felicidade financiada: crédito, consumo(mismo) e (super)endividamento do consumidor. Revista de Direito da Procuradoria Geral do Estado de Goiás, Belo Horizonte, ano 29, n.31, jan./dez. 2016. p. 9
} 
superendividado repousam justamente na análise se ao contratar as dívidas não adimplidas ele encontrava-se ou não de boa-fé. ${ }^{17}$

Isso porque a boa-fé é princípio corolário das relações contratuais, e a tutela do indivíduo dentro de uma relação de contrato só se faz justa se ele tiver agido de acordo com o que descreve tal diretriz principiológica. ${ }^{18}$

Quando se fala em superendividamento ativo consciente está sendo considerado o caso do consumidor que, sabendo que não possui condições financeiras de adimplir o débito contratado, escolhe mesmo assim concluir o negócio jurídico. ${ }^{19}$

Essa postura demonstra uma típica demonstração de má-fé contratual, uma vez que o superendividado ativo consciente sabe que seu credor ficará em situação de prejuízo, não merecendo dessa forma a tutela estatal..$^{20}$

Situação diferente, contudo, é a do superendividado ativo inconsciente. Nesse caso, a situação do endividamento excessivo surge sem que o consumidor perceba que está contraindo débitos acima de suas capacidades, realizando, assim, seus contratos de boa-fé. ${ }^{21}$

Variadas são as razões que levam ao quadro do superendividamento do consumidor e, dessa maneira, será feita a análise no próximo tópico das possíveis causas que geram o superendividamento na sua forma passiva e ativa, com foco nesse último para a sua forma inconsciente.

17 LIMA, Bruna Giacomini; FERREIRA, Vitor Hugo do Amaral . Tempos de Consumo e vulnerabilidade potencializada: a necessária (re)leitura dos direitos fundamentais diante da proteção do consumidor idoso superendividado. Anais do VIII Seminário Internacional de Demandas Sociais e politicas Publicas na Sociedade contemporânea , v. 1, 2015. p. 8

${ }^{18}$ FANECO, Lívia Carvalho da Silva. Superendividamento do consumidor: análise das decisões do Superior Tribunal de Justiça acerca do contrato de cartão de crédito. Dissertação (Mestrado em Desenvolvimento no Estado Democrático de Direito) - Faculdade de Direito de Ribeirão Preto, Universidade de São Paulo, Ribeirão Preto, 2016. p. 87

${ }_{19}$ FRANCO, Vera Helena de Mello. O Sobre-Endividamento do Consumidor: os Modelos: Estado Atual da Questão Perante o Direito Alienígena. Revista de Direito do Consumidor: RDC, São Paulo, v. 24, n. 99, Revista dos Tribunais, 2015 .p. 11

${ }^{20}$ WODTKE, Guilherme Domingos Gonçalves. O Superendividamento Do Consumidor: As Possíveis Previsões Legais Para Seu Tramento. Disponível em: http://conteudo.pucrs.br/wp-ontent/uploads/sites/11/2017/03/ guilherme_wodtke_2014_2.pdf. p.5

${ }^{21}$ SUZART Joseane. O Superendividamento dos Consumidores Brasileiros e a Imprescindível Aprovação do Projeto de Lei 3.515/15. Revista de Direito do Consumidor, v. 100, 2015. p. 6 


\section{POSSÍVEIS CAUSAS DO SUPERENDIVIDAMENTO DO CONSUMIDOR}

Diversos são os motivos que podem levar a pessoa natural, nas relações de consumo que estabelece em sua vida diária, a contrair débitos superiores à sua capacidade financeira para adimpli-los.

Esses motivos podem ser anteriores à contração da dívida ou até mesmo posteriores a ela, sendo nesse último caso, por muitas vezes, causas do superendividamento passivo. E é justamente essa forma de endividamento a primeira a ter suas causas apontadas por este trabalho.

Como mencionado anteriormente, o conceito de superendividamento passivo está relacionado a um endividamento que não foi causado por uma conduta do indivíduo, mas por um fator externo à pessoa do endividado que influencia as finanças deste e o impede de adimplir suas dívidas.

Como exemplos de fatores externos capazes de abalar a condição financeira de um indivíduo podem ser apontados o desemprego, a necessidade de realizar gastos médicos por ocasião de uma doença, falecimento na família que cause dispêndios com serviços funerários, ou até mesmo um divórcio, que pode vir a abalar o conjunto patrimonial do sujeito que a ele se submete..$^{22}$

Todavia, não são apenas os eventos alheios à vontade do indivíduo os causadores do quadro de endividamento excessivo. Muitas vezes, agindo de boafé a pessoa acaba contraindo débitos muito acima do que é capaz de suportar economicamente, colocando em risco suas condições de vida.

Tais fatores ligados à vontade do indivíduo podem ser analisados sob prismas distintos e, assim, serão trabalhadas separadamente as razões que podem ser causadoras do endividamento ativo inconsciente.

\subsection{MOTIVAÇÃO ECONÔMICA}

A economia capitalista contemporânea tem como base de funcionamento o consumo de bens e serviços para movimentação das engrenagens do capital e geração de novas riquezas, em uma dinâmica que demonstra clara mudança de eixos da economia capitalista de produção para aquela de consumo ${ }^{23}$

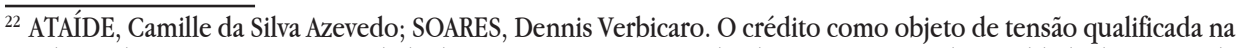
relação de consumo e a necessidade de prevenção ao superendividamento. Revista da Faculdade de Direito da UFRGS, Porto Alegre, n. 36, v. Esp., out. 2017. p. 6

${ }^{23}$ FORNASIER, Mateus de Oliveira. Sociedade de hiperconsumo, dignidade e superendividamento: uma abordagem hermenêutica. Revista do Instituto de Hermenêutica Jurídica - RIHJ, Belo Horizonte, ano 13, n. 18, p. 37-57, jul./dez. 2015. p. 47 
No panorama econômico atual, destaca-se o mercado de fornecimento de crédito, com o oferecimento de produtos como os empréstimos e os cartões de crédito. O crédito caracteriza-se como uma troca de valores diferida no tempo que se opera pela aplicação de taxas de juros. ${ }^{24}$

A oferta de crédito tornou-se um dos pilares da economia de consumo ${ }^{25}$, servindo como fator primordial para recuperação de economias em períodos de crise e com a aplicação de juros sobre os valores comprados atuando como molas impulsionadoras da produção de novos capitais. ${ }^{26}$

Nesse quadro, o acesso ao crédito aos consumidores torna-se fácil, com a oferta grandemente difundida e a criação de modalidades creditórias que facilitam a obtenção do crédito e permitem que maiores números de consumidores tenham acesso a essa forma de compra temporalmente dilatada. ${ }^{27}$

Modalidades como o empréstimo consignado e os financiamentos tornam acessível a criação dessa forma de débito a pessoas que muitas vezes não têm condições de arcar com os pagamentos futuros que são contratados. ${ }^{28}$

Além do fácil acesso ao sistema de crédito existente, a prestação de informações quanto ao serviço de fornecimento de crédito deixa a desejar, causando, por muitas vezes, confusão naqueles que contratam tal serviço. ${ }^{29}$

Muitas vezes a ausência de clareza na forma de explicação em como funcionam os sistemas de juros e taxas nas contratações de crédito levam o consumidor a contrair um débito que coloca em risco sua saúde financeira e por muitas vezes, o leva a uma situação de superendividamento..$^{30}$

Assim, ao serem pensadas legislações que visem solucionar a questão do

${ }^{24}$ CARNEIRO, Ana Luiza Marinho. Buying money: indebted 's profile and causal attributions by consumers, bank managers and financial educators in credit use. Dissertação (Mestrado em Psicologia Social, do Trabalho e das Organizações) - Universidade de Brasília, Brasília, 2016. p. 13

${ }^{25}$ GAULIA, Cristina Tereza. O Abuso de Direito na Concessão de Crédito: O Risco do Empreendimento Financeiro na Era do Hiperconsumo. Doutrinas Essenciais de Direito do Consumidor, v. 3, Revista dos Tribunais, 2011. p. 5

${ }^{26}$ JANTALIA, Fabiano. A revisão judicial de taxas de juros em contratos bancários: uma análise crítica sob o prisma do direito econômico. Dissertação (Mestrado em Direito) - Universidade de Brasília, Brasília, 2010. p. 22.

${ }^{27}$ CONDINO, Olivia. Op. Cit. p. 26

${ }^{28}$ GAGLIETTI, Mauro José; DORST, Daeane Zulian. Os Conflitos Sociais no Âmbito do Superendividamento e a Mediação como Forma de Tratá-Los. Revista de Direito do Consumidor, v. 107, Revista dos Tribunais, 2016 .p. 10

${ }^{29}$ LIMA, Clarissa Costa de. Medidas Preventivas Frente ao Superendividamento dos Consumidores na União Europeia. Revista de Direito do Consumidor, v. 76, Revista dos Tribunais, 2010. p. 2

${ }^{30}$ LIMA, Clarissa Costa de. O Cartão de Crédito e o Risco de Superendividamento. Uma Análise da Recente Regulamentação da Indústria de Cartão de Crédito no Brasil e nos Estados Unidos. Revista de Direito do Consumidor, v. 81, 2012. p. 6 
superendividamento, os aspectos econômicos de mercado devem ser levados em consideração para que se tenha uma solução efetiva e completa da questão.

\subsection{MOTIVAÇÃO PSICOLÓGICA}

Para além das razões de caráter econômico, há forte componente psicológico que influencia os consumidores superendividados. Deve ser levado em conta que os elementos cognitivos que circundam a tomada de decisões na contratação de débitos possuem peso considerável no surgimento do fenômeno aqui estudado.

$\mathrm{Na}$ tomada de decisões, o comportamento humano nem sempre é guiado pelo caminho mais racional nas escolhas de condutas. Ao comprar algo, muitas vezes não se é levado em consideração o custo-benefício advindo daquela operação, mas outras motivações menos racionalizadas, em um comportamento analisado nos estudos das heurísticas. ${ }^{31}$

As heurísticas podem ser entendidas como as decisões quase automáticas e que possuem a aparência de estarem certas tomadas pelas pessoas em um primeiro impulso, em um mecanismo mental de resolução de questões difíceis de forma rápida. ${ }^{32}$

Assim, levando em consideração tal conceito, sabe-se que os consumidores possuem a tendência de adotar uma postura demasiadamente otimista em relação à sua condição financeira, retirando o impacto que eventos futuros e incertos podem trazer à sua estabilidade econômica, o que contribui para a criação da situação de superendividamento. ${ }^{33}$

Além disso, a possibilidade de obtenção do crédito, já analisada anteriormente, influencia de forma psicológica os consumidores, uma vez que ao deferir no tempo a obrigação de pagamento do produto que se obteve com o valor do crédito, a sensação de estar obrigado a adimplir uma dívida deixa de estar ligada ao objeto adquirido e adquire uma feição própria, deslocada do prazer trazido pelo ato de consumir, o que aprofunda a possibilidade do consumidor superendividarse. ${ }^{34}$

${ }^{31}$ CARNEIRO, Ana Luiza Marinho. Op. Cit. p. 80

32 OLIVEIRA, Amanda Flávio De; CARVALHO, Diógenes Faria de. Vulnerabilidade comportamental do consumidor: por que é preciso proteger a pessoa superendividada. Revista de Direito do Consumidor, v. 104, 2016. p. 4

33 OLIVEIRA, Amanda Flávio De; CARVALHO, Diógenes Faria de. Op. Cit. p. 6

${ }^{34}$ OLIVEIRA, Amanda Flávio De; CARVALHO, Diógenes Faria de. Op. Cit. p. 9 
Desse modo, o aspecto psicológico do consumidor deve ser considerado ao serem pensadas leis e medidas de direito que visem trazer soluções ao fenômeno do endividamento excessivo, para que se alcance o resultado esperado por tais medidas legais.

\subsection{MOTIVAÇÃO SOCIAL}

Para além dos motivos já citados, resta ainda a análise do contexto social no qual se desenvolve o superendividamento. A sociedade atual pode ser classificada como uma sociedade de hiperconsumo. ${ }^{35}$

Nesse tipo de organização social, o consumo movimenta não apenas o aspecto econômico da vida dos indivíduos, mas também determina sua posição no contexto de interação social. A definição de quem a pessoa corresponde ao que ela é capaz de consumir e sua relevância social passa a ser medida pela sua capacidade de compra de bens e serviços. ${ }^{36}$

Destarte, toda a construção do maquinário social transita pelo ideário do consumo e assim são produzidos os bens com durabilidade reduzida, para que as pessoas necessitem comprar mais, e é feito um investimento maciço em publicidade, que bombardeia os consumidores diariamente. ${ }^{37}$

Comprar se torna então a chave de inserção no contexto social, no qual o encaixe só se realiza se o indivíduo for capaz de consumir. ${ }^{38}$ Nessa sistemática surgem os superendividados, que compram além do que conseguem pagar e colocam em risco sua saúde financeira para atender aos anseios da sociedade no qual estão inseridos.

À vista disso, a criação de normas que visam controlar a situação do endividamento além das capacidades financeiras dos indivíduos deve atentar-se às questões como a publicidade continua e a demanda social para que se consuma cada vez mais.

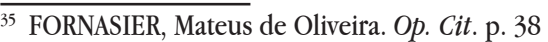

${ }^{36}$ FORNASIER, Mateus de Oliveira. Op. Cit. p. 38

${ }^{37}$ MARTINS, Guilherme Magalhães; ARAUJO, Stella de Souza Ribeiro de; MIGUEL, Laila Natal. O protagonismo judicial e o superendividamento dos consumidores no Brasil. Revista de Direito do Consumidor , v. 109, Revista dos Tribunais, 2017. p. 3

${ }^{38}$ CARVALHO, Diógenes Faria de ; FERREIRA, Vitor Hugo do Amaral. Op. Cit. p. 3
} 


\section{UMA BREVE VISÃO GERAL DO TRATAMENTO DA QUESTÃO NA LEGISLAÇÃO DOS PAÍSES ESTRANGEIROS}

O problema do superendividamento do consumidor longe de ser um problema exclusivamente nacional vem sendo enfrentado por diversos países ao redor do mundo que trazem, cada um deles, soluções diversas para uma mesma problemática.

Todas essas soluções têm em comum a ideia de proteção ao consumidor que se encontra superendividado. Elas gravitam ao redor da intenção de reinserir na roda da economia esse indivíduo para que ele seja capaz de voltar a consumir sem que sua dignidade seja ferida.

Será apresentado, a seguir, um panorama geral dos modelos legais adotados por alguns países, mormente os casos da França, dos Estados-Unidos, da Itália e da Colômbia, para a compreensão de como são as abordagens de cada legislação apresentada na tentativa de reestabelecer a dignidade do consumidor superendividado.

Cumpre ressaltar os critérios de seleção dos modelos legais dos países supramencionados. Os modelos francês e norte-americano, por terem servido de inspiração para o desenvolvimento do projeto de lei brasileiro sobre o tema, ${ }^{39}$ será explanado no próximo tópico.

Já o sistema italiano, justifica-se a sua análise, em razão do legislador ter criado todo um procedimento em torno da composição da crise de superendividamento, optando por saídas conciliativas na resolução dessas questões que envolvem o consumidor.

O sistema colombiano, por sua vez, nos apresenta um método de realização de mediações, um tratamento peculiar, nas quais mediadores são treinados para atuarem junto ao devedor e seus credores, e encontrar saídas que possibilitem o adimplemento dos débitos através de um plano de pagamento, respeitando-se a dignidade da pessoa humana. 


\subsection{O SISTEMA FRANCÊS}

No sistema francês, o código do consumidor, com a modificação sofrida em 2016, dedicou todo seu livro VII ao tratamento da situação de superendividamento. Inicialmente, o legislador francês deixa claro que as situações ali reguladas aplicamse somente aos consumidores pessoas físicas que atuaram de boa-fé. ${ }^{40}$

O Code de la consommation também determina que serão criadas comissões para tratar os casos de superendividamento dos indivíduos. ${ }^{41}$ Esse é o primeiro ponto de destaque do sistema francês: a delegação a uma comissão que buscará solucionar os casos de superendividamento, e não a indicação direta do juízo singular para a solução do tema, sendo a comissão responsável por decidir se o caso deverá ser submetido a juízo. ${ }^{42}$

O pedido de tratamento da situação do endividamento excessivo é feito pelo próprio devedor à comissã ${ }^{43}$, e se essa comissão decidir favoravelmente ao pedido realizado suspendem-se as execuções pelos credores contra o patrimônio do devedor. ${ }^{44}$

Tal medida demonstra um cuidado da legislação francesa em proteger a dignidade do superendividado garantindo um mínimo patrimonial para que ele garanta sua sobrevivência de forma digna.

A comissão então decidirá como serão distribuídos os rendimentos do devedor, ${ }^{45}$ determinando a quantia destinada à quitação de seus débitos e a quantia que permanecerá reservada para a garantia da subsistência do devedor e de sua família, baseada nos valores de despesas apresentados por ele ${ }^{46}$ novamente demonstrando o esmero legislativo em garantir uma reinserção digna do consumidor endividado no mercado.

O plano de recuperação financeira do devedor é elaborado pela comissão, que notifica aos credores e ao devedor que devem assinar e datar o plano, caso concordem $^{47}$. Caso a conciliação entre as partes falhe, a comissão tem autonomia

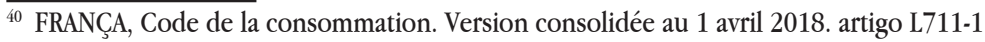

${ }^{41}$ FRANÇA, Op. Cit. artigo L712-1

${ }^{42}$ FRANÇA, Op. Cit. artigo L712-2

${ }^{43}$ FRANÇA, Op. Cit. Artigo L721-1

${ }^{44}$ FRANÇA, Op. Cit. Artigo L722-2

${ }^{45}$ FRANÇA, Op. Cit., Artigo R731-1

${ }^{46}$ FRANÇA, Op. Cit. Artigo R731-3

${ }^{47}$ FRANÇA, Op. Cit. Artigo R732-1/3
} 
para determinar por conta própria medidas para pagamento dos débitos ${ }^{48}$. $\mathrm{O}$ plano ainda pode ser contestado, com a comissão enviando a contestação para o juízo competente $^{49}$, que seguirá o procedimento delimitado nos artigos R733-10 em diante do Code.

\subsection{O SISTEMA NORTE-AMERICANO}

Já no direito norte-americano, as disposições referentes ao superendividamento do consumidor são regidas pelos capítulos 7 e 13 do Bankruptcy Code, tendo cada um deles um procedimento diverso para a tentativa de solucionar o problema do consumidor superendividado..$^{50}$

A Suprema Corte Norte-Americana recomenda que se candidatem ao procedimento descrito no capítulo 13 as pessoas que possuam rendas familiares constantes e que possam assim, submeter-se a um plano de débitos. ${ }^{51}$

O procedimento regulado pelo capítulo 7 seria, por outro lado, destinado às pessoas que não se adequariam ao capítulo 13 e que não realizaram acordos com seus credores..$^{52} \mathrm{~A}$ submissão ao capítulo 7 tornou-se mais difícil desde a edição do Bankruptcy Abuse Prevention and Consumer Protection Act of 2005, que impôs limitações ao uso do mencionado capítulo.53

Os bankrupctcy cases são submetidos às Bankruptcy Courts e, quando os devedores ingressam com um caso regulado pelo capítulo 7, a corte decide, por meio de um trustee (uma espécie de administrador de bens com função semelhante à do administrador judicial descrito no sistema brasileiro de recuperação judicial de empresas) se os casos apresentados enquadram-se nos parâmetros necessários, analisando se a situação será reclassificada para o capítulo 13 ou até mesmo rejeitado. $^{54}$

Assevera o capítulo 7 do Bankruptcy Act of 1978 que as pessoas naturais que se candidatarem ao procedimento ali descrito não necessitam cumprir um

${ }^{48}$ FRANÇA, Op. Cit. Artigo L733-1

${ }^{49}$ FRANÇA, Op. Cit. Artigo R733-9

${ }^{50}$ ROJAS VERTIZ, Rosa. Op. Cit, p. 6

${ }^{51}$ ESTADOS UNIDOS, United States Courts, Chapter 7 - Bankruptcy Basics, Alternatives to Chapter 7, 2018. Disponível em http://www.uscourts.gov/services-forms/bankruptcy/bankruptcy-basics/chapter-7-bankruptcybasics. Acesso em: 27 abr. 2018.

52 ESTADOS UNIDOS, United States Courts, Op. Cit. Alternatives to Chapter 7. Acesso em: 27 abr. 2018.

${ }^{53}$ MÜLLER, Karsten, Busy Bankruptcy Courts and the Cost of Credit. 2017. Disponível em: https://ssrn.com/ abstract $=3088676$. p 8

${ }^{54}$ MÜLLER, Karsten, Op. Cit. p 8 
plano de pagamento de débitos. Nos casos regidos por este capítulo, o conjunto patrimonial do devedor é arrecadado pelo trustee e vendido para quitar as dívidas com os credores 5 , sendo a ordem de pagamento dos credores é definida de acordo com a seção 726 do Banckruptcy Code. ${ }^{56}$

Alguns dos bens integrantes do patrimônio do devedor podem permanecer sob sua pose, caso ele comprove a necessidade de manutenção de tais bens consigo para garantia de sua dignidade humana. ${ }^{57}$

Existe a possibilidade de discharge do devedor, caso seja procedida a liquidação de alguns bens determinados. O discharge nada mais é do que uma espécie de perdão das dívidas restantes para que o devedor possa ter um "novo começo" (fresh start) em sua vida financeira e possa reinserir-se no mercado consumidor. ${ }^{58}$

Esse mecanismo de liberação dos débitos ainda remanescentes funda-se na ideia de que a falha que deu origem à situação do superendividamento não é só do devedor que contraiu as dívidas, mas também de toda a estrutura de mercado no qual ele está inserido. ${ }^{59}$

No procedimento pelo capítulo 13, por sua vez, o devedor ingressa com o pedido de submissão ao procedimento descrito no mencionado capítulo para o desenvolvimento de um plano de pagamentos dos débitos. Tal plano, se aprovado, se estende por períodos de três a cinco anos, em média, ${ }^{60} \mathrm{e}$ é voltado, basicamente, para os devedores que possuem uma entrada regular de rendimentos em seu conjunto patrimonial. ${ }^{61}$

O pagamento dos débitos é feito pelo trustee designado para cuidar daquele caso específico do devedor, uma vez que, o devedor repassa a ele os valores destinados no plano para pagamentos e o trustee, então, efetua o pagamento de acordo com a ordem de credores. ${ }^{62}$

\footnotetext{
${ }^{55}$ FRANCO, Vera Helena de Mello. Op. Cit. p. 3

${ }^{56}$ ESTADOS UNIDOS, United States Courts, Chapter 7 - Bankruptcy Basics, Role of the Case Trustee, 2018. Disponível em http://www.uscourts.gov/services-forms/bankruptcy/bankruptcy-basics/chapter-7-bankruptcybasics. Acesso em: 27 abr. 2018.

${ }^{57}$ ROJAS VERTIZ, Rosa. Op. Cit. p. 6

${ }^{58}$ FRANCO, Vera Helena de Mello. Op. Cit. p. 3

${ }^{59}$ FANECO, Lívia Carvalho da Silva. Op. Cit. p. 67

${ }^{60}$ ESTADOS UNIDOS, United States Courts, Chapter 13 - Bankruptcy Basics. 2018. Disponivel em: http://www. uscourts.gov/services-forms/bankruptcy/bankruptcy-basics/chapter-13-bankruptcy-basics. Acesso em: 27 abr. 2018.

${ }^{61}$ ROJAS VERTIZ, Rosa. Op. Cit. p. 7

${ }^{62}$ ROJAS VERTIZ, Rosa. Op. Cit. p. 7
} 
A admissão do mencionado plano pode resultar na suspensão de execuções existentes contra o devedor em situação de superendividamento e, se completado o plano, o resultado será uma discharge order (ordem de liberação) pela qual o devedor será considerado livre de seus débitos, ainda que todos não tenham sido quitados. ${ }^{63}$

\subsection{OS CASOS DE ITÁLIA E COLÔMBIA}

No direito italiano, no ano de 2012, foi aprovada a disciplina que tratava dos casos de superendividamento de pessoas físicas pela lei $\mathrm{n}^{\mathrm{o}} 3 / 2012$, tendo sido posteriormente, mas naquele mesmo ano, aprovado um procedimento para os consumidores na lei $n^{0}$ 221/2012. ${ }^{64}$

Segundo dispõe a lei $\mathrm{n}^{\mathrm{0}}$ 3/2012 em seu texto, criou-se todo um procedimento em torno da ideia de composição da crise de superendividamento. ${ }^{65}$ Desse modo, percebe-se que a legislação italiana tratou o caso da pessoa física superendividada como uma situação crítica, optando por saídas conciliativas na resolução dessas questões que envolvem o consumidor.

O procedimento, com as alterações trazidas pela lei $n^{0} 221 / 2012$, trata da elaboração de um plano de pagamento e recuperação elaborado pelo devedor e apresentado aos credores em um processo de composição entre as partes envolvidas. ${ }^{66}$

Nesse plano devem estar contidas informações como a ordem de pagamento dos credores, as garantias apresentadas e a forma de liquidação dos bens do devedor para cumprimento do plano de quitação dos débitos contraídos.$^{67} \mathrm{O}$ plano deve ser então submetido a um tribunal e, se aceito, impedirá a abertura de execuções em face do devedor em razão das dívidas abarcadas no plano de recuperação. ${ }^{68}$

No caso colombiano, as medidas para tratamento do consumidor superendividado são tratadas como um caso de insolvência da pessoa física e regulados pela lei $n^{0} 1564 / 2012$. Segundo tal legislação, apenas os devedores são capazes de ingressar com um procedimento de recuperação, e nunca os credores,

\footnotetext{
$\overline{63}$ ROJAS VERTIZ, Rosa. Op. Cit. p. 7

${ }^{64}$ BERTUZZI, Martina. Op. Cit. p. 52

65 BERTUZZI, Martina. Op. Cit.p. 58

${ }^{66}$ FRANCO, Vera Helena de Mello. Op. Cit. p. 15

${ }^{67}$ FRANCO, Vera Helena de Mello. Op. Cit. p. 15

${ }^{68}$ FRANCO, Vera Helena de Mello. Op. Cit. p. 16
} 
reforçando assim a ideia de reabilitação presente na mencionada legislação. ${ }^{69}$

O método utilizado é o da realização de mediações nas quais mediadores treinados tentarão, junto ao devedor e seus credores, encontrar saídas que possibilitem o adimplemento dos débitos por meio de um plano de pagamento, sem que seja ferida a dignidade humana do devedor. ${ }^{70}$

Esse fato demonstra, assim, uma preocupação da lei colombiana com a busca por métodos alternativos de solução de conflitos, uma vez que ocorre apenas a vigilância do processo pelas cortes locais, com a posterior aprovação do plano elaborado. ${ }^{71}$

Em síntese, a análise dos modelos legais adotados pela França, EstadosUnidos, Itália e Colômbia para o tratamento do fenômeno do superindividamento evidencia soluções díspares, ao mesmo tempo em que se revela a preocupação do legislador em reestabelecer a dignidade humana do consumidor superendividado.

\section{O TRATAMENTO DADO AO SUPERENDIVIDAMENTO DO CONSUMIDOR NO BRASIL}

No âmbito do direito brasileiro, as relações de consumo são reguladas pelo Código de Defesa do Consumidor (CDC), lei n ${ }^{\circ}$ 8.078/1990. Nessa lei estão contidas, em seus artigos $1^{\circ}, 2^{\circ}$ e $3^{\circ}$, as definições de consumidor, fornecedor e relação de consumo.

Ademais, o CDC abarcou em seu texto diversos princípios que devem reger as relações de consumo, destacando-se entre eles o princípio da vulnerabilidade do consumidor, que opera em nível de direito material e determina que todos os consumidores são vulneráveis, sendo esse requisito básico para que se caracterize uma relação de consumo, sob tutela das regras dispostas no CDC.72

Os casos de superendividamento dos consumidores, todavia, não possuem ainda uma disciplina específica no Brasil, que vise proteger o consumidor que se encontra em uma situação na qual suas dívidas superam sua capacidade de adimplilas, colocando em risco sua saúde financeira e a manutenção de sua dignidade humana.

\footnotetext{
${ }_{69}$ ROJAS VERTIZ, Rosa. Op. Cit. p. 17

${ }^{70}$ ROJAS VERTIZ, Rosa. Op. Cit. p. 18

${ }^{71}$ ROJAS VERTIZ, Rosa. Op. Cit. p. 18

${ }^{72}$ BRAGA NETTO, Felipe Peixoto. Manual de Direito do Consumidor: À Luz da Jurisprudência do STJ. 11 ed. rev, atual. e ampl. Juspodivm, Salvador, 2016. p. 60
} 
Existem, contudo, projetos voltados à solução do problema do endividamento excessivo dos consumidores brasileiros. O primeiro deles foi um projeto organizado pelo Tribunal de Justiça do Rio Grande do Sul (TJ-RS) que se voltava para a realização de conciliações entre os devedores superendividados e seus credores.

Há também, ainda em tramitação no congresso nacional, o projeto de lei do Senado Federal $n^{0}$ 283/2012 que visa alterar o atual texto do CDC para incluir um capítulo voltado à disciplina do superendividamento do consumidor e a criação de procedimentos para tratamento desse fenômeno. Ambas as medidas serão tratadas de forma mais detalhada a seguir.

\subsection{OPROJETO-PILOTO“TRATAMENTODASSITUAÇÕESDESUPERENDIVIDAMENTO DO CONSUMIDOR"}

Nos anos de 2006 e 2007, o TJ-RS, juntamente com o programa de pósgraduação da Universidade Federal do Rio Grande do Sul, desenvolveu um projeto com vistas a encontrar soluções viáveis e compatíveis com o cenário nacional para o superendividamento dos consumidores ${ }^{73}$, uma vez que não existiam medidas legislativas que tratavam especificamente dos casos do consumidor superendividado.

$O$ projeto se constituiu na realização de audiências de renegociação das dívidas entre os consumidores e seus credores, sob a coordenação de juízes integrantes do TJ-RS e participação dos alunos da UFRGS, que auxiliam as partes interessadas na melhor forma de composição do conflito existente entre eles. ${ }^{74}$

A ideia do projeto baseia-se no sistema europeu de tratamento dos superendividados, semelhante aos modelos francês e italiano apresentados nesse trabalho, que consistem na elaboração de planos de recuperação do consumidor em dívida. ${ }^{75}$

Tal projeto tinha intrínseco a si um caráter pedagógico que objetivava a reeducação do consumidor superendividado, para que ele não voltasse a contrair dívidas superiores à sua capacidade financeira e que colocam em risco sua manutenção própria e familiar. ${ }^{76}$

\footnotetext{
${ }^{73}$ LIMA, Clarissa Costa de; BERTONCELLO, Karen Rick Danilevicz. Adesão ao Projeto Conciliar é Legal - CNJ: Projeto Piloto. Tratamento das situações de superendividamento do consumidor. Revista de Direito do Consumidor: RDC, v. 16, n. 63, jul./set. 2007. Revista dos Tribunais, 2007. p. 13

${ }^{74}$ LIMA, Clarissa Costa de; BERTONCELLO, Karen Rick Danilevicz. Op. Cit. p. 14

${ }^{75}$ LIMA, Clarissa Costa de; BERTONCELLO, Karen Rick Danilevicz. Op. Cit p. 17

${ }^{76}$ LIMA, Clarissa Costa de; BERTONCELLO, Karen Rick Danilevicz. Op. Cit p. 18
} 
Podiam participar do projeto, os consumidores que, de boa fé, contraíram obrigações além do que poderiam suportar, enquadrando-se nos conceitos já trabalhados de superendividados passivos e ativos inconscientes. ${ }^{77} \mathrm{O}$ procedimento adotado pelo projeto é de realização de audiências de conciliação extrajudiciais ou judiciais, a depender do caso.

Se ainda não houvesse nenhum processo judicial em face do devedor para cobrança das dívidas oriundas da relação de consumo, e o próprio consumidor procurasse a organização do projeto, as audiências teriam caráter extrajudicial e o procedimento teria início pelo preenchimento de um formulário pelo devedor. ${ }^{78}$

Se, no entanto, já existisse um procedimento judicial de cobrança da dívida contra o devedor, não seria esse motivo de impedimento para aplicação do projeto, que poderia ainda ser utilizado como uma solução alternativa para o conflito existente. ${ }^{79}$

O consumidor superendividado receberia, antes da audiência, uma cartilha que tinha como objetivo principal, atender ao pressuposto do projeto de ensinar o consumidor a evitar o fenômeno do endividamento excessivo, cumprindo o papel de prevenção a novos casos. ${ }^{80}$

A totalidade de credores do consumidor superendividado seria então reunida em uma audiência conciliatória e, juntos, tentariam chegar a um plano de pagamento que permitisse a recuperação financeira do consumidor e o pagamento das obrigações contraídas. ${ }^{81}$

Os resultados do projeto foram significativos, uma vez que, conforme os dados reunidos pelas magistradas organizadoras, cerca de $81,5 \%$ das audiências realizadas resultou em uma conciliação frutífera entre as partes. ${ }^{82}$

Tal fato que demonstra que os métodos alternativos de solução de conflitos talvez sejam um caminho adequado para a solução dos casos de superendividamento no Brasil, o que se conecta com o próximo tópico a ser discutido, a existência de um projeto de lei no congresso nacional que busca regular o tratamento do superendividamento nacional.

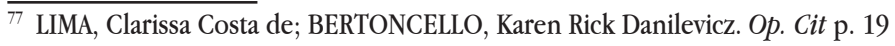

${ }^{78}$ LIMA, Clarissa Costa de; BERTONCELLO, Karen Rick Danilevicz. Op. Cit, p. 18

${ }^{79}$ LIMA, Clarissa Costa de; BERTONCELLO, Karen Rick Danilevicz. Op. Cit, p. 18

${ }^{80}$ LIMA, Clarissa Costa de; BERTONCELLO, Karen Rick Danilevicz. Op. Cit, p. 23

${ }^{81}$ LIMA, Clarissa Costa de; BERTONCELLO, Karen Rick Danilevicz. Op. Cit, p. 26

82 LIMA, Clarissa Costa de; BERTONCELLO, Karen Rick Danilevicz. Op. Cit, p. 32
} 


\subsection{O PROJETO DE LEI DO SENADO FEDERAL No 283/2012}

Com a finalidade de regular os casos do fenômeno trabalhado nesse artigo no Brasil, foi apresentado no Senado Federal o projeto de lei (PL) no 283/2012, que, atualmente, encontra-se sujeita à apreciação do plenário da Câmara dos Deputados sob o número PL 3515/2015.

Esse projeto tem por escopo trazer alterações ao texto da lei $\mathrm{n}^{\circ}$ 8.078/1990, o Código de Defesa do Consumidor, e ao artigo 96 do Estatuto do Idoso (lei $\mathrm{n}^{\mathrm{o}}$ 10.741/2003), para que sejam inseridas normas de prevenção ao superendividamento e aperfeiçoamento das normas de fornecimento de crédito ao consumidor, com objetivo de que se evitem novos casos de endividamento excessivo. ${ }^{83}$

As primeiras alterações que se buscam trazer no texto do CDC dizem respeito aos princípios que regem a política nacional das relações de consumo. Foi pensada pelo legislador a adição de dois novos incisos ao artigo $4^{\circ}$ da lei de consumo, voltados para a prevenção do surgimento dos casos de superendividamento.

$\mathrm{O}$ primeiro dos incisos visa o fomento de ações voltadas à educação financeira dos consumidores e o segundo volta-se a enxergar o tratamento aos casos de superendividamento como uma forma de evitar-se a exclusão social dos consumidores nessa situação. ${ }^{84}$

Para que as medidas acrescentadas possam ser efetivadas, foram elaboradas alterações nos mecanismos de execução da política nacional das relações de consumo, tendo sido projetados também dois novos incisos que passariam a integrar o artigo $5^{\circ}$ do CDC.

$\mathrm{O}$ primeiro deles institui mecanismos judiciais e extrajudiciais para prevenção e tratamento dos casos de pessoas naturais superendividadas. É interessante ressaltar a preocupação com a criação de mecanismos paralelos à via judicial, em uma correlação com o conceito de justiça multiportas, priorizandose métodos alternativos de solução de litígios que antes eram resolvidas por via judicial. O segundo inciso corrobora essa posição estabelecendo a criação de núcleos de conciliação e mediação para resolução dos casos provenientes do superendividamento.

Foram inseridos também novos direitos do consumidor, com a inclusão de três novos incisos no artigo $6^{\circ}$ da lei de consumo. $\mathrm{O}$ foco das novas inserções

\footnotetext{
$\overline{83}$ BRASIL. Senado Federal. Projeto de Lei no 283, de 2012. p. 1

${ }^{84}$ BRASIL. Senado Federal. Op. Cit. p. 1
} 
é claramente a garantia da preservação da dignidade da pessoa do consumidor endividado, uma vez que se cria o direito à prática do crédito responsável, à revisão e repactuação de dívidas, à educação financeira, à existência de um mínimo existencial e a informação detalhada quanto aos preços de bens e serviços oferecidos. ${ }^{85}$

O texto do projeto de lei traz alterações também no que tange à publicidade voltada ao consumidor, alterando o texto do artigo 37 do CDC para considerar abusiva a publicidade que incite o consumidor a tomar atitudes lesivas à sua saúde e segurança, bem como proíbe a publicidade voltada ao público infantil que contenha conteúdo apelativo ou que implique na criação de um sentimento de inferioridade por não consumir ${ }^{86}$, em uma clara relação com a prevenção de possíveis causas do superendividamento (psicológica e social).

Foram inseridos no projeto também incisos adicionais ao artigo 51, que comtemplam novas hipóteses de abusividade nas cláusulas contratuais, destacandose entre elas as que impedem o acesso ao judiciário por parte do consumidor e consideram o silêncio do contratante como anuência a condições de aumentos de valores obrigacionais, ${ }^{87}$ novamente atingindo uma das causas geradoras do fenômeno do superendividamento (razão econômica).

A grande inovação trazida pelo PL 283/2012 é, todavia, a criação de capítulos destinados completa e diretamente ao tratamento dos casos de superendividamento do consumidor pessoa natural, mencionando-se inicialmente o capítulo VI-A intitulado "Da prevenção e do Tratamento do Superendividamento".

Foi trazida no art. 54-A, $\S 1^{\circ}$ uma definição do fenômeno que muito se assemelha às já trabalhadas aqui, que 0 considera “(...) a impossibilidade manifesta de o consumidor, pessoa natural, de boa-fé, pagar a totalidade de suas dívidas de consumo, exigíveis e vincendas, sem comprometer seu mínimo existencial, nos termos da regulamentação" ${ }^{88}$

É importante mencionar que o texto proposto exclui a hipótese de proteção ao consumidor superendividado ativo consciente, expressando no $\S 3^{\circ}$ do mencionado artigo que não se aplicam as disposições aos consumidores que dolosamente contraírem obrigações com o objetivo de não adimpli-las ou que tenham contratado mediante fraude ou má fé. ${ }^{89}$

\footnotetext{
$\overline{85}$ BRASIL. Senado Federal. Op. Cit. p. 1

${ }^{86}$ BRASIL. Senado Federal. Op. Cit. p. 2

${ }^{87}$ BRASIL. Senado Federal. Op. Cit. p. 2

${ }^{88}$ BRASIL. Senado Federal. Op. Cit. p. 3

${ }^{89}$ BRASIL. Senado Federal. Op. Cit. p. 3
} 
Há ainda uma preocupação evidente com o direito de informação do consumidor, sendo inserido o dever dos credores de fornecimento detalhado de informações, com explicações de funcionamento de taxas de juros, encargos entre outras obrigações integrantes dos contratos..$^{90}$

Isso porque o legislador parece entender que o esclarecimento do consumidor quanto aos termos do contrato a que se submete é crucial para que ele possa, após compreender os termos que rodeiam a obrigação, contratar apenas aquilo que tem, de fato, condições de adimplir.

Outro ponto que merece destaque é a possibilidade, trazida no artigo 54E, $\S 2^{\circ}$, de desistência por parte do consumidor do crédito consignado contratado em até sete dias após a contratação de tal forma de crédito, sem a necessidade de informar o motivo ${ }^{11}$, o que se acredita ser a posição do legislador de considerar o fornecimento de crédito um dos causadores do superendividamento do consumidor.

O PL 283/2012 traz também a criação do capítulo V, destinado à conciliação nos casos em que o superendividamento se manifesta. É criada, no artigo 104-A, a possibilidade de elaboração de um plano de recuperação que pode estender-se por até cinco anos, elaborado em um ato conciliatório que reúne o devedor e seus credores, ${ }^{92}$ com similaridade aos modelos francês e americano e similar também ao modelo já implantado no projeto piloto anteriormente mencionado.

$\mathrm{O} \$ 4^{\circ}$ do mencionado artigo prescreve que plano deverá conter a forma de pagamento das dívidas, com a indicação de dilação de prazos e descontos oferecidos, a referência à suspensão ou extinção das ações judiciais em curso e a data de exclusão do consumidor do cadastro de inadimplentes, em uma clara demonstração da tentativa de recuperação do indivíduo endividado em excesso e a reinserção dele no mercado de consumo.

Em síntese, o que se pode vislumbrar, até o momento, é que transcorridas quase três décadas de sua vigência, o Código de Defesa do Consumidor continua assegurando direitos, entretanto, as transformações ocorridas durante esse interregno na economia, na política e na vida cultural da sociedade brasileira trouxeram demandas que não foram contempladas pelo legislador, e o fenômeno do superendividamento é uma dessas imprevisões, que hoje se situa dentre os grandes problemas nacionais.

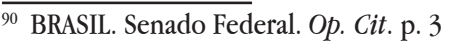

${ }^{91}$ BRASIL. Senado Federal. Op. Cit. p. 5

${ }^{92}$ BRASIL. Senado Federal. Op. Cit. p. 7
} 
O projeto de lei do Senado $\mathrm{n}^{\mathrm{o}} 383 / 2012$, proposto com o fim precípuo de atualizar o Código de Defesa do Consumidor, surge como uma alternativa para os consumidores, dispondo sobre a prevenção do superendividamento. Caso venha a ser aprovado, passa a contemplar no art. $4^{\circ}$, inciso IX do Código de Defesa do Consumidor ações com o fito de estimular o Estado e a sociedade a promover a educação financeira dos consumidores, devendo o tema ser contemplado em currículos escolares, o que certamente propicia ao consumidor meios para a utilização do crédito de forma responsável e consciente, coibindo o seu superendividamento.

Assim, uma vez aprovado, o PLS n ${ }^{0}$ 283/2012 determina a instituição de mecanismos de prevenção e tratamento extrajudicial e judicial do superendividamento e de proteção do consumidor pessoa natural. (art. $\left.5^{\circ}, \mathrm{VI}\right)$; a instituição de núcleos de conciliação e mediação de conflitos oriundos de superendividamento. $\left(5^{\circ}, \mathrm{VII}\right)$; a garantia de práticas de crédito responsável, de educação financeira e tratamento das situações de superendividamento, por intermédio da revisão e da repactuação da dívida, dentre outras medidas. $\left(5^{\circ}, \mathrm{XI}\right)$; Na repactuação de dívidas e na concessão de crédito, a preservação do mínimo existencial, compreendido como a quantia mínima destinada à manutenção das despesas de sobrevivência do consumidor. $\left(5^{\circ}\right.$, XII).

Somada à proposta legislativa em trâmite no Congresso Nacional, cumpre salientar que os entes federados podem e devem promover mecanismos extrajudiciais de prevenção e tratamento dos consumidores superendividados; algumas iniciativas nesse sentido já existem no país como, por exemplo, no Distrito Federal, onde são promovidas renegociações e quitações de dívidas, dentre acordos judiciais e préprocessuais.

Além disso, podem ser ampliados alguns programas visando abarcar as demandas da sociedade que podem contribuir para o endividamento, como descontrole das finanças pessoais, desemprego, adoecimentos, vulnerabilidade das pessoas idosas nas relações de consumo e distúrbios de comportamento, como, por exemplo, a compulsão por compras.

Com um atendimento multidisciplinar, os órgãos de defesa do consumidor, ao lado de setores da sociedade civil podem realizar mesas redondas, palestras, oficinas, sessões de orientação financeira e encaminhamento psicossocial, levando orientação aos consumidores com em processos judiciais em tramitação, e ao 
cidadão que esteja em orientação financeira. E ainda, a educação financeira deve ser valorizada cada vez mais nas escolas, no sentido de promover o empodeiramento do consumidor, por meio da educação financeira, consciente do seu papel como sujeito ativo na relação de consumo.

\section{CONCLUSÃO}

O superendividamento dos consumidores é um problema contemporâneo que possui uma dimensão global, fenômeno presente na sociedade brasileira que atinge grande parcela dos consumidores nacionais. Diversas são as soluções encontradas pelo direito estrangeiro e a legislação brasileira caminha na direção de encontrar sua própria saída para esse problema.

A criação de um capítulo especializado ao assunto no código de defesa do consumidor, se aprovado, representará um avanço louvável na busca da resolução dos casos de superendividamento no Brasil, tendo destaque a iniciativa da busca de soluções extrajudiciais para tal problema, que já se mostrou efetivo, como se verifica dos resultados do projeto piloto implantado no Rio Grande do Sul.

A solução no campo legal, contudo, não operará resultados sozinha, tendo em vista as diversas causas do superendividamento, sendo necessário também trabalhar o aspecto psicológico dos consumidores nessa situação, para prevenir novas incidências no mesmo problema e frear os impulsos de consumo, quando for essa a principal causa do fenômeno, tendo, dessa forma, a educação a respeito do superendividamento um importantíssimo peso no seu combate.

Como exemplos de sugestões que vão além da atuação no campo legal para solucionar o problema do superendividamento, preservando a dignidade do consumidor nessa condição, podem-se apresentar aquelas elaboradas no Parecer do Comitê Econômico e Social Europeu, após a análise dos resultados de pesquisa sobre tal fenômeno na União Europeia.

O Estado não deve ser um fim em si mesmo, daí a importância de serem aplicados no Brasil projetos de educação econômica nas escolas ${ }^{93}$, em uma abordagem econômica e psicológica, para a formação de uma mentalidade que vise

$\overline{93}$ COMITÊ ECONÔMICO E SOCIAL EUROPEU. Parecer do Comité Económico e Social Europeu sobre o tema Defesa dos consumidores e gestão adequada do sobre-endividamento para prevenir a exclusão social. 2014. Disponível em https://www.eesc.europa.eu/en/our-work/opinions-information-reports/opinions/consumerprotection-and-over-indebtedness. p. 14. 
o consumo consciente e se ensine assim, desde a fase de formação dos cidadãos, uma conduta que os garanta uma situação digna quando ingressarem ativamente no mercado consumidor.

Além disso, poderiam ser implementadas campanhas ${ }^{94}$, seja em nível nacional, ou até mesmo em nível local, que visem ensinar os consumidores a praticar o consumo de forma sustentável e a balancear seus gastos e rendimentos.

Destarte, a aplicação de medidas legais que visem combater o superendividamento, juntamente com a adoção de medidas socioeducativas que tenham como foco prevenir o surgimento do problema mostram-se como possíveis soluções para coibir o fenômeno do superendividamento do consumidor no Brasil.

\section{REFERÊNCIAS}

ANDRADE, Fabio Siebeneichler, ROSA, Taís Hemann da. Notas Sobre a Tutela do Consumidor Superendividado no Brasil: um novo caso de proteção da pessoa contra si mesmo (atualidades e perspectivas). Revista Arquivo Jurídico - Revista Jurídica Eletrônica da UFPI, v. 2, p. 81-104, 2015. Disponível em: http://www.ojs. ufpi.br/index.php/raj/article/view/4508. Acesso em: 27 abr. 2018.

ATAÍDE, Camille da Silva Azevedo; SOARES, Dennis Verbicaro. O crédito como objeto de tensão qualificada na relação de consumo e a necessidade de prevenção ao superendividamento. Revista da Faculdade de Direito da UFRGS, Porto Alegre, n. 36, v. esp., p. 73-89, out. 2017. Disponível em: http://www.seer.ufrgs.br/ index.php/revfacdir/article/view/72782. Acesso em: 27 abr. 2018.

BERTUZZI, Martina. Il sovraindebitamento del consumatore. Università Degli Studi di Roma "Roma Tre". Quinto premio OCI per laureati con tesi sulle discipline concorsuali della crisi d'impresa, 2016. Disponível em: https://www. osservatorio-oci.org/index.php?option $=$ com_phocadownload $\&$ view $=$ category $\&$ $\mathrm{id}=208$ :quinto-premio-oci-per-laureati-con-tesi-sulle-discipline-concorsuali-dellacrisi-d-impresa\&Itemid=885. Acesso em: 27 abr. 2018.

BRAGA NETTO, Felipe Peixoto. Manual de Direito do Consumidor: À Luz da Jurisprudência do STJ. 11 ed. rev, atual. e ampl. Juspodivm, Salvador, 2016. 
BRASIL. Senado Federal. Projeto de Lei $\mathbf{n}^{\mathbf{0}}$ 283, de 2012. Disponível em: https:// www25.senado.leg.br/web/atividade/materias/-/materia/106773. Acesso em: 27 abr. 2018.

CARNEIRO, Ana Luiza Marinho. Buying money: indebted's profile and causal attributions by consumers, bank managers and financial educators in credit use. 2016. 95f. Dissertação (Mestrado em Psicologia Social, do Trabalho e das Organizações ) - Universidade de Brasília, Brasília, 2016. Disponivel em: http:// repositorio.unb.br/handle/10482/22207. Acesso em: 27 abr. 2018.

CARVALHO, Diógenes Faria de ; FERREIRA, Vitor Hugo do Amaral. Felicidade financiada: crédito, consumo(mismo) e (super)endividamento do consumidor. Revista de Direito da Procuradoria Geral do Estado de Goiás, Belo Horizonte, ano 29, n.31, jan./dez. 2016. Disponível em: http://www.bidforum.com.br/bid/ PDI0006.aspx?pdiCntd=243391. Acesso em: 26 jan. 2018.

COMISSÃO EUROPEIA. Over-indebtedness - New evidence from the EU-SILC special module. Research note 4/2010, Social Situation Observatory: Living Conditions and Income Distribution, 2010. Disponível em: ec.europa.eu/social/ BlobServlet?docId=6708\&langId =em. Acesso em: 18 maio 2018.

\section{COMITÊ ECONÔMICO E SOCIAL EUROPEU. Parecer do Comitê Econômico e} Social Europeu sobre o tema Defesa dos consumidores e gestão adequada do sobre-endividamento para prevenir a exclusão social. 2014. Disponível em https://www.eesc.europa.eu/en/our-work/opinions-information-reports/opinions/ consumer-protection-and-over-indebtedness. Acesso em: 18 maio 2018.

CONDINO, Olivia. Il sovraindebitamento del consumatore. Il Diritto degli Affari, E-Book n. 4, Milano, 2013. Disponivel em: http://www.ildirittodegliaffari.it/ebook/5. Acesso em: 27 abr. 2018.

CONFEDERAÇÃO NACIONAL DO COMÉRCIO DE BENS, SERVIÇOS E TURISMO. Pesquisa Nacional de Endividamento e Inadimplência do Consumidor, 2018. Disponível em: http://cnc.org.br/central-do-conhecimento/pesquisas/economia/ pesquisa-de-endividamento-e-inadimplencia-do-consumidor-3. Acesso em 18 maio 2018.

ESTADOS UNIDOS, United States Courts, Chapter 13 - Bankruptcy Basics. 2018. Disponivel em: http://www.uscourts.gov/services-forms/bankruptcy/bankruptcy- 
basics/chapter-13-bankruptcy-basics. Acesso em: 27 abr. 2018.

ESTADOS UNIDOS. United States Courts, Chapter 7 - Bankruptcy Basics, 2018. http://www.uscourts.gov/services-forms/bankruptcy/bankruptcy-basics/chapter-7bankruptcy-basics. Acesso em: 27 abr. 2018.

FANECO, Lívia Carvalho da Silva. Superendividamento do consumidor: análise das decisões do Superior Tribunal de Justiça acerca do contrato de cartão de crédito. 2016. Dissertação (Mestrado em Desenvolvimento no Estado Democrático de Direito) - Faculdade de Direito de Ribeirão Preto, Universidade de São Paulo, Ribeirão Preto, 2016. Disponível em: http://www.teses.usp.br/teses/ disponiveis/107/107131/tde-01092017-080249/. Acesso em: 27 abr. 2018.

FORNASIER, Mateus de Oliveira. Sociedade de hiperconsumo, dignidade e superendividamento: uma abordagem hermenêutica. Revista do Instituto de Hermenêutica Jurídica - RIHJ, Belo Horizonte, ano 13, n. 18, p. 37-57, jul./dez. 2015. Disponível em https://bdjur.stj.jus.br/jspui/handle/2011/97703. Acesso em: 27 abr. 2018.

FRANÇA, Code de la consommation. Version consolidée au 1 avril 2018. Disponível em: https://www.legifrance.gouv.fr/affichCode. do;jsessionid $=$ F86048EC113CD06065C1037E6EEDE0CB.

tplgfr26s_2?cidTexte $=$ LEGITEXT000006069565\&dateTexte $=20180403$. Acesso em: 27 abr. 2018.

FRANCO, Vera Helena de Mello. O Sobre-Endividamento do Consumidor: os Modelos: Estado Atual da Questão Perante o Direito Alienígena. Revista de Direito do Consumidor: RDC, São Paulo, v. 24, n. 99, p. 333-370, 2015.

GAGLIETTI, Mauro José; DORST, Daeane Zulian. Os Conflitos Sociais no Âmbito do Superendividamento e a Mediação como Forma de Tratá-Los. Revista de Direito do Consumidor, v. 107, p. 485-507, 2016.

GAULIA, Cristina Tereza. O Abuso de Direito na Concessão de Crédito: O Risco do Empreendimento Financeiro na Era do Hiperconsumo. Doutrinas Essenciais de Direito do Consumidor, v. 3, p. 807-835, 2011.

JANTALIA, Fabiano. A revisão judicial de taxas de juros em contratos bancários: uma análise crítica sob o prisma do direito econômico. 2010. xv. 196 f. Dissertação (Mestrado em Direito) -Universidade de Brasília, Brasília, 2010. Disponivel em http:// repositorio.unb.br/handle/10482/7701. Acesso em: 27 abr. 2018. 
LIMA, Bruna Giacomini; FERREIRA, Vitor Hugo do Amaral. Tempos de Consumo e vulnerabilidade potencializada: a necessária (re)leitura dos direitos fundamentais diante da proteção do consumidor idoso superendividado. In: ANAIS DO XII SEMINÁRIO INTERNACIONAL DE DEMANDAS SOCIAIS E POLÍTICAS PUBLICAS NA SOCIEDADE CONTEMPORÂNEA, v. 1, 2015. Anais eletrônicos [...]. Disponível em https://online.unisc.br/acadnet/anais/index.php/sidspp/article/view/13182. Acesso em: 27 abr. 2018.

LIMA, Bruna Giacomini; FERREIRA, Vitor Hugo do Amaral. Da Ruína à Reconstrução do Homo Economicus: Os (Des) Encontros da Sociedade de Consumo na Interface do Direito, Cidadania e Políticas Públicas. In: ANAIS DO XII SEMINÁRIO INTERNACIONAL DE DEMANDAS SOCIAIS E POLÍTICAS PUBLICAS NA SOCIEDADE CONTEMPORÂNEA, v. 1, 2015. Anais eletrônicos [...]. Disponível em http://online.unisc.br/acadnet/anais/index.php/sidspp/issue/view/56. Acesso em: 27 abr. 2018.

LIMA, Clarissa Costa de. Medidas Preventivas Frente ao Superendividamento dos Consumidores na União Europeia. Revista de Direito do Consumidor, v. 76, p. 208-238, 2010.

LIMA, Clarissa Costa de. O Cartão de Crédito e o Risco de Superendividamento. Uma Análise da Recente Regulamentação da Indústria de Cartão de Crédito no Brasil e nos Estados Unidos. Revista de Direito do Consumidor, v. 81, p. 239$261,2012$.

LIMA, Clarissa Costa de; BERTONCELLO, Karen Rick Danilevicz. Adesão ao Projeto Conciliar é Legal - CNJ: Projeto Piloto. Tratamento das situações de superendividamento do consumidor. Revista de Direito do Consumidor: RDC, v. 16, n. 63, p. 173-201, jul./set. 2007. Disponível em http://bdjur.stj.jus.br/dspace/ handle/2011/85834. Acesso em: 27 abr. 2018.

MARTINS, Guilherme Magalhães; ARAUJO, Stella de Souza Ribeiro de; MIGUEL, Laila Natal. O protagonismo judicial e o superendividamento dos consumidores no Brasil. Revista de Direito do Consumidor, v. 109, p. 113-139, 2017.

MÜLLER, Karsten. Busy Bankruptcy Courts and the Cost of Credit, 2017. Disponível em: https://ssrn.com/abstract=3088676. Acesso em: 27 abr. 2018. 
comportamental do consumidor: por que é preciso proteger a pessoa superendividada. Revista de Direito do Consumidor, v. 104, p. 181-202, 2016.

PALHARES, Cinara. A tutela do consumidor excessivamente endividado como forma de preservação dos direitos fundamentais da pessoa humana. 2010. Dissertação (Mestrado em Direito Civil) - Faculdade de Direito, Universidade de São Paulo, São Paulo, 2010. Disponível em http://www.teses.usp.br/teses/ disponiveis/2/2131/tde-13122010-161854/pt-br.php. Acesso em: 27 abr. 2018.

PRUX, Oscar Ivan. Os 25 anos do Código de Proteção e Defesa do Consumidor, sua história e as novas perspectivas para o século XXI. Revista de Direito do Consumidor, v. 104, p. 17-63, 2016.

QUEIROZ, Sheyla Cristina Ferreira dos Santos. Superendividamento do Consumidor: os contratos de crédito pessoal por idosos e a responsabilidade penal do fornecedor. 2016. 134f. Dissertação (Mestrado em Ciências Jurídicas) - Universidade Federal da Paraíba, João Pessoa, 2016. Disponível em http://tede. biblioteca.ufpb.br:8080/handle/tede/8258. Acesso em: 27 abr. 2018.

ROJAS VERTIZ, Rosa, Is There Consumer Bankruptcy in Latin America? The Cases of Colombia, Brazil and Peru, 2017. Disponível em https://ssrn.com/ abstract $=2996808$. Acesso em: 27 abr. 2018.

SCHMIDT NETO, André Perin. Superendividamento do consumidor: conceito, pressupostos e classificação. Revista de Direito do Consumidor, v. 71, p. 9-33, 2009.

SUZART Joseane. O Superendividamento dos Consumidores Brasileiros e a Imprescindível Aprovação do Projeto de Lei 3.515/15. Revista de Direito do Consumidor, v. 100, p. 361-391, 2015.

WODTKE, Guilherme Domingos Gonçalves. O Superendividamento do Consumidor: as possíveis previsões legais para seu tramento. Disponível em: http://conteudo.pucrs.br/wp-content/uploads/sites/11/2017/03/guilherme_ wodtke_2014_2.pdf. Acesso em: 27 abr. 2018. 